\title{
Ukrainian entrepreneurship in Italy: factors influencing the creation of ethnic ventures
}

\author{
Diego Matricano and Mario Sorrentino*
}

\author{
* Correspondence: \\ mario.sorrentino@unina2.it \\ Department of Management, \\ Second University of Naples, Corso \\ Gran Priorato di Malta, 81043 Capua \\ (CE), Italy
}

\begin{abstract}
This paper investigates the factors affecting the creation of ethnic ventures in the enclave in order to determine whether immigrants can be considered opportunity or necessity entrepreneurs. The results are helpful to proceed with further reflections on how immigrants perceive the context they are in and on what should be done to foster their social and economic integration.

In order to achieve the final aim, three categories of factors - pull, push and socio-demographic - affecting the creation of ethnic ventures in the enclave are considered and tested. Data were obtained from a questionnaire survey that was administered to Ukrainian entrepreneurs in the Municipality of Caserta in southern Italy. The results of a logistic regression model indicate that the factors affecting the creation of new Ukrainian ventures are housing area and age: if immigrants live outside the enclave and they are younger than forty years old, then they are more likely to create new ethnic ventures in the enclave. These results demonstrate that the Ukrainians in Caserta perceive the context they are in as unfavourable: they are necessity entrepreneurs who create new ventures just to overcome the discrimination and exclusion that they experience. Implications for policy makers and suggestions for future research are discussed in the last part of the paper.
\end{abstract}

Keywords: Ethnic entrepreneurs; Opportunity and necessity entrepreneurs; Push and pull factors; New venture creation

\section{Background}

There is a general consensus among scholars that immigrants contribute to the economic development of the countries they settle in (Razin and Langlois 1996). Indeed, as noted by Zhou (2004), ethnic entrepreneurs create new job opportunities, decrease market competition, develop new business models and increase earnings for themselves and for the country where they live.

The considerable growth of immigrant involvement in entrepreneurial activities has driven scholars worldwide to investigate the phenomenon along three main lines. The first deals with the creation of ethnic ventures in the destination country (Waldinger 1985; Sanders and Nee 1987; Aldrich et al. 1989, 1990; Cobas and DeOllos 1989; Aldrich and Waldinger 1990; Rafiq 1992; Villar 1994; Barrett et al. 1996; Razin and Langlois 1996; Lee 1999; Chaganti and Greene 2002; Lofstrom 2002; Masurel et al. 2002; Pécoud 2004; Volery 2007; de Haas 2010; Matricano, 2011a). The second concerns the possible growth trajectories of ethnic ventures - for example through

\section{黛 Springer}

(C) 2014 Matricano and Sorrentino; licensee Springer. This is an Open Access article distributed under the terms of the Creative 
the break-out process (Ram and Hillin 1994, Matricano and Sorrentino 2012). Lastly, there is the focus on the creation and growth of ethnic ventures in the origin and destination countries contemporaneously - properly termed transnational entrepreneurship (Ong and Nonini 1997; Ong 1999; Guarnizo et al. 2003; Drori et al. 2009).

Choosing the line to follow in the present paper was relatively straightforward: migration towards Italy is a recent phenomenon in comparison to other countries (Martiniello 2000) and, consequently, immigrant participation in entrepreneurship is at an embryonic phase. Most of the ethnic ventures created in Italy are still in the early stage of their life cycle. Hence, in the present paper, we focus only on the first aspect proposed above - i.e. that concerning the creation of ethnic ventures in the destination country. In line with the growing interest shown by policy makers, scholars and practitioners, the aim of the paper is to investigate the factors affecting the creation of new ethnic ventures in the destination country and to shed some light on how immigrants perceive the context they are in. Particular attention is paid to the creation of ethnic ventures in the enclave, those parts of cities where immigrants live and work in the destination country.

Generally speaking, the creation of new ethnic ventures in the destination country can be studied according to two main theoretical frameworks. The former is based on the combination of contextual factors and characteristics of the ethnic group to which the entrepreneur belongs (Kloosterman et al. 1999). The latter is based on the factors pulling or pushing immigrants towards entrepreneurship (Chrysostome 2010). Despite the development of these theoretical frameworks at an international level, in reference to the Italian context there emerges a considerable gap. Several authors have used the first theoretical framework and some interesting insights have already been found (Santi 1995; Ambrosini 2000; Palidda 2000; Ceccagno 2003; Chiesi and Zucchetti 2003); few authors have used the second, achieving results that do not seem robust enough (Ganzaroli et al. 2008; Chiesi 2011). In order to reduce this gap, the theoretical model used in the present paper is based on the dualist pull vs. push factors and the research question we try to answer is: which are the factors, classified as pull or push, affecting the creation of ethnic ventures in the enclaves?

The remainder of this paper is structured as follows. Section 'The characteristics of opportunity and necessity entrepreneurs' reviews the entrepreneurial literature in order to draw the profiles of opportunity and necessity entrepreneurs and to clarify how they perceive the context they are in. Section 'Conceptual framework and hypotheses' contains the theoretical framework used to investigate the phenomenon. After defining the dependent variable - the creation of ethnic ventures in enclaves - hypotheses about pull, push and socio-demographic factors are developed. Section 'Research design' describes the process of data collection and contains the descriptive statistics. The results of the logistic regression model are presented in section 'The results of the logistic regression' and they show that housing area and age of entrepreneurs affect the creation of ethnic ventures in the enclave. In the last section, the results are discussed, conclusions are drawn and some implications for future research are proposed, despite the possible limitations.

\section{The characteristics of opportunity and necessity entrepreneurs}

As already stated, the final aim of the present paper is to determine whether immigrants in Italy can be considered opportunity or necessity entrepreneurs and to discuss how they perceive the context they are in. 
In 2001 and 2002, the reports published by the Global Entrepreneurship Monitor (Reynolds et al. 2001, 2002) stressed the concepts of opportunity and necessity entrepreneurs and so many additional scholars (Maritz 2004; Smallbone and Welter 2004; Harding et al. 2006; Minniti et al. 2006; Sternberg et al. 2006; Block and Wagner 2007) contributed to an already existing field of research (Washington 1971; Boyd 1990; Butler 1991; Portes and Zhou 1992; Light et al. 1994; Fairlie and Meyer 1996). Since then, the distinction between opportunity and necessity entrepreneurs has been used in reference to several topics such as policies to manage businesses, the results achieved and the survival time (Verheul et al. 2010) and in reference to different targets like female (McClelland et al. 2005; Robichaud et al. 2010) or ethnic entrepreneurs (Kerr and Schlosser 2007; Chrysostome and Arcand 2009; Chrysostome 2010).

To make the opportunity versus necessity dualism useful for the present study, it is necessary to draw the two different profiles of opportunity and necessity entrepreneurs (Shinnar and Young 2008; Chrysostome 2010) and especially highlight the main differences in reference to how ethnic entrepreneurs perceive the context they are in. Generally speaking (Reynolds et al. 2001, 2002), opportunity entrepreneurs start an entrepreneurial activity because they perceive a chance, an option and they try to exploit it - this is what De Freitas (1991) calls mobility motives. They recognize the context they are in as positive and so they are more prone to act in order to achieve their entrepreneurial aim. By contrast, necessity entrepreneurs are victims of unfavourable working circumstances. Accordingly, they decide to launch a new ethnic venture because they do not have any working alternative in the mainstream market (Light and Bonacich 1988; Waldinger et al. 1990; Bailey and Waldinger 1991; Feagin and Imani 1994). They realize the negative context around them and so they perceive the achievement of their entrepreneurial aims as a challenge - this is what De Freitas (1991) calls escape motives.

According to several scholars (Shapero and Sokol 1982; Gilad and Levine 1986; Stevenson 1986; Storey 1994; Buttner and Moore 1997; Clark and Drinkwater 2000; Harding et al. 2006; Uhlaner and Thurik 2007; Robichaud et al. 2010), some factors can be instrumental to identify opportunity and necessity entrepreneurs. Pull factors lead to the straight identification of opportunity entrepreneurs who make an intentional choice to become entrepreneurs because they are aware of their entrepreneurial capabilities (Uhlaner and Thurik 2007). Moreover, they are 'pulled' by the need for achievement and the desire to be independent, as well as social development possibilities (Verheul et al. 2010). Through the exploitation of an entrepreneurial opportunity, they aim to increase income, be autonomous, create their own jobs, have no boss and develop new products/services or processes (Giacomin et al. 2011). In short, the pull factors are all the favourable, encouraging motivations that can bring immigrants closer to entrepreneurship in a positive context.

Push factors, instead, lead to the direct identification of necessity entrepreneurs who evaluate the possibility to become entrepreneurs as a response to dissatisfaction with their working conditions (Verheul et al. 2010). This means that they are pushed towards the search and exploitation of an entrepreneurial opportunity: the decision to become entrepreneurs is due to the frustration they perceive in reference to their occupational status. In brief, push factors are all the unfavourable, overwhelming motivations that can bring immigrants closer to entrepreneurship in a negative context. 
Other factors, mainly concerning socio-demographic aspects of ethnic entrepreneurs, cannot lead to directly identifying opportunity and necessity entrepreneurs. Such controversial factors, concerning the housing area, age, years of residence in the destination country, level of education and gender, can be classified as pull or push factors according to the influence they can have (Shinnar and Young 2008). If they are perceived as favourable, then they are included among the pull factors and are useful to identify opportunity entrepreneurs; on the contrary, if they are perceived as unfavourable, they are included among the push factors and are helpful to identify necessity entrepreneurs.

\section{Conceptual framework and hypotheses}

In order to determine whether immigrants in Italy can be considered opportunity or necessity entrepreneurs, a conceptual framework is proposed. This framework enables us to test whether pull, push or socio-demographic factors (independent variables) can affect the creation of new ethnic ventures in the enclave (dependent variable).

The first group includes the pull factors such as the possibility to get start-up capital, hire employees, obtain inputs, sell outputs, overcome institutional problems, replicate a business model and exploit managerial competences. These factors are all the favourable, encouraging motivations that can bring immigrants closer to entrepreneurship in a positive context and that identify opportunity entrepreneurs. The second category comprises push factors such as lack of satisfaction perceived by immigrants in reference to their working conditions due to a probable state of unemployment and the willingness to change an unsatisfactory job. These factors are all the unfavourable, overwhelming motivations that can bring immigrants closer to entrepreneurship in a negative context and that identify necessity entrepreneurs. As already stated, the last category contains sociodemographic factors like housing area, age, number of years spent in the destination country, level of education and gender. These factors can lead to the identification of both opportunity and necessity entrepreneurs according to whether they are perceived positively or negatively by immigrants.

The relationship between the three categories of factors and the creation of ethnic ventures in the enclave is shown in Figure 1.

\section{Dependent variable}

The dependent variable included in the theoretical model is the creation of new ethnic ventures - generally speaking, new ventures can be considered as the nexus of entrepreneurial actions (Sorrentino 2012) - in the enclave. As was stated above, the enclaves are welllimited areas of cities where immigrants live and work (Light et al. 1994; Portes 1995; Light and Gold 2000). The choice of this dependent variable is in line with the evolution of the studies on ethnic entrepreneurship. Over the years, several scholars have underlined the relevance of the enclave and very interesting studies have been conducted (Boyd 1990; Peterson and Roquebert 1993; Light et al. 1994; Portes 1995; Razin and Langlois 1996; Basu 1998; Kloosterman et al. 1999; Le 2000; Light and Gold 2000; Flota and Mora 2001; Kloosterman and Rath 2001; Clark and Drinkwater 2002; Kloosterman 2003; Parker 2004; Zhou 2004; Volery 2007). Among them, Basu (1998), for example, has investigated three enclaves (Indian, Bengali and Pakistani) in the UK in order to compare 


\begin{tabular}{|c|c|c|}
\hline $\begin{array}{l}\text { Pull factors } \\
\end{array}$ & \multirow{25}{*}{$\rightarrow$} & \multirow{25}{*}{$\begin{array}{c}\text { Creation } \\
\text { of ethnic } \\
\text { ventures } \\
\text { in the } \\
\text { enclave }\end{array}$} \\
\hline H1: Start-up capital personally saved or loaned by family members (PFC) & & \\
\hline H2: Start-up capital loaned by members of the ethnic group (EGC) & & \\
\hline H3: Start-up capital loaned by local banks (LBC) & & \\
\hline H4: Employees belonging to the family (FE) & & \\
\hline H5: Employees belonging to the ethnic group (EGE) & & \\
\hline H6: Employees belonging to other ethnic groups (OEGE) & & \\
\hline H7: Ethnic inputs from the ethnic group in the destination country (EGI) & & \\
\hline H8: Ethnic inputs from the ethnic group in the origin country $(\mathrm{OCI})$ & & \\
\hline H9: Inputs from other ethnic groups (OEGI) & & \\
\hline H10: Ethnic outputs to already existing ethnic markets (EMO) & & \\
\hline H11: Ethnic outputs to potential ethnic markets (PEMO) & & \\
\hline H12: Outputs to other ethnic groups (OEGO) & & \\
\hline H13: Institutional problems (IP) & & \\
\hline H14: Business model (BM) & & \\
\hline H15: Managerial competences (MC) & & \\
\hline Push factors & & \\
\hline H16: Unemployment (GOU) & & \\
\hline H17: Previous work (LPW) & & \\
\hline Socio-demographic factors & & \\
\hline H18: Housing area (HA) & & \\
\hline H19: Age (AGE) & & \\
\hline H20: Amount of years spent in the destination country (YDC) & & \\
\hline H21: Level of education (LE) & & \\
\hline H22: Gender (GEN) & & \\
\hline Source: Personal elaboration & & \\
\hline igure 1 The conceptual framework. & & \\
\hline
\end{tabular}

inclinations towards entrepreneurship between different ethnic groups in their enclaves. Kloosterman (2003) carried out a similar study in the Netherlands, while Zhou (2004) focused his attention on Chinatown, the Chinese enclave in New York. Italian studies about enclaves show a certain delay since some ethnic groups have not yet created their own enclave and so they do not live and work inside it. However, the cases of established enclaves that have been studied deal with the African and Chinese enclaves in Milan (Breveglieri et al. 1997, 2000) and, perhaps the most famous case, the Chinese enclave in Prato (Bressan et al. 2008).

All these studies underline the importance of enclaves and confirm our choice to consider as a dependent variable of the conceptual framework the creation of new ethnic ventures in the enclave. As for the methodological aspects, the creation of an ethnic venture in the enclave is measured as a binary variable coded 0 if the ethnic venture was created outside the enclave, and 1 if the venture was created inside the enclave.

\section{Independent variables and hypotheses}

Pull factors

The group of pull factors includes the factors that allow identification of opportunity entrepreneurs who start up an entrepreneurial activity because they perceive a chance and then try to exploit it. They recognize the context they are in as positive and so they act in a very committed way in order to achieve their final goal.

Start-up capital In line with the entrepreneurial literature, start-up capital is one of the main factors affecting the creation of new ethnic ventures in the enclave (Light 1972; Kim and Hurh 1985; Ram 1994; Ram and Deakins 1996; Bates 1997; Deakins et al. 1997; Lee et al. 1997; Fadahunsi 2000; Chrysostome and Arcand 2009). 
Immigrants who are engaged in the creation of new ethnic ventures need to evaluate all the possible sources of start-up capital that may be personal savings, family, friends or banks.

According to several scholars (Kim and Hurh 1985; Yoon 1991; Bates 1997), personal savings and loans from the family represent very important sources of start-up capital. In reference to both, immigrants' families play an important role: they can help the ethnic entrepreneur to save a start-up capital or they can save money and then loan it (Nee and Nee 1973; Basu and Altinay 2002). The main characteristics of support that ethnic entrepreneurs can obtain from their families are as follows: there is no formal application process and there are no interest rates to pay (Chrysostome and Arcand 2009) and, in addition, there is no loan repayment deadline. Accordingly, the support offered by the family represents a promising opportunity on which immigrants can leverage in order to create a new ethnic venture. Thus, it may be hypothesized that

H1: The more favourable are conditions for saving start-up capital or accessing startup capital loaned by family members, the higher is the likelihood of creating ethnic ventures in the enclave.

The members of the ethnic group also represent possible funders who can provide start-up capital. According to Ram (1994), the choice to loan start-up capital to members of the same ethnic group is one of the best examples of solidarity among immigrants. Of course, the loan of start-up capital takes place when the ethnic social network is very strong (Yoon 1991; Bates 1997; Deakins et al. 1997; Lee et al. 1997); otherwise, there is no support between co-ethnic members. The importance of start-up capital loaned by other members of the ethnic group is due to the fact that the positive aspects underlined above in reference to the family (no application process, no high rates of interest and no deadline to pay it back) are still valid. Also in this case, the above encouraging aspects denote an opportunity to exploit in a positive context. Therefore, it may be hypothesized that

H2: The more favourable are conditions for access to start-up capital loaned by members of the ethnic group, the higher is the likelihood of creating ethnic ventures in the enclave.

Generally speaking, immigrants have to overcome several difficulties in order to access start-up capital from formal local institutions (Light 1972; Ram and Deakins 1996; Deakins et al. 1997; Lee et al. 1997; Kloosterman et al. 1998). However, according to a report published by the Bank of England (1999), financing problems faced by ethnic entrepreneurs are similar to those encountered by local entrepreneurs. Hence, the main reason why ethnic entrepreneurs do not obtain start-up capital from local banks can be sought in the theory of 'discouraged borrowers' (Kon and Storey 2003; Fraser 2009). According to this theory, ethnic entrepreneurs wrongly perceive access to local start-up capital as disproportionately difficult and so they tend to prevent themselves accessing start-up capital loaned by local banks. This theory seems to be confirmed by the fact that increasing numbers of institutions implement policies to finance entrepreneurial projects by immigrants (Hussain and Martin 2005; Irwin and Scott 2006; Hussain and Matlay 2007; Chrysostome 2010). Some examples are provided by the US government that supports Minority Business Enterprise Programs; in Canada, the Maytree Foundation supports the Immigrant Employment Loan Program, and the Mennonite Central Committee (MCC) Employment Development supports the Immigrant Access Fund (Atallah and Rebelo 2006). As noted in a report published by the Italian Bankers 
Association - ABI (2008), also in Italy, several banks have launched dedicated initiatives to offer services to immigrants (see also CeSPI 2004). All these programmes, conceived and implemented in favour of immigrants, represent a chance for them to obtain the necessary start-up capital. Thus, it may be hypothesized that

H3: The more favourable are conditions for access to start-up capital loaned by local banks, the higher is the likelihood of creating ethnic ventures in the enclave.

Employees Another important factor that can affect the creation of ethnic ventures in the enclave deals with co-ethnic employees who share the same ethnic background as the entrepreneur (Bonacich and Modell 1980; Evans 1989; Waldinger et al. 1990; Zhou 1992; Bates 1994; Basu and Goswani 1999; Basu and Altinay 2002; Min and Bozorgmehr 2003; Altinay and Altinay 2006). The importance of co-ethnic workers is due to several reasons. First of all, co-ethnic workers are familiar with the customs and language of the entrepreneur. They know the right manners to be used and how to interact with co-ethnics. The most important aspect to underline is that the ability to speak the same language makes relationships with suppliers and customers much easier. Secondly, co-ethnic workers are low-cost, loyal and willing to accept demanding work schedules. This mainly occurs because of informal ties with their employer.

As a rule, employees can be members of the family or of the same ethnic group (Portes 1995). In the first case, when employees are family members, informal ties are very strong. Indeed, the family-oriented workplace inspires loyalty, flexible work practices, higher productivity, better communication through a shared family language, lower transaction costs (wages) and informal decision making (Kerr and Schlosser 2007). Hiring employees from the same family is an encouraging option through which the family is confirmed as the primary basis of trust and collective action (Boyd 1989; Aldrich and Waldinger 1990; Waldinger et al. 1990). Hence, it may be hypothesized that

H4: The more favourable it is to employ family members, the higher is the likelihood of creating ethnic ventures in the enclave.

Even if the employees do not belong to the original family but to the ethnic group, the ties linking the employer and the employees still remain strong. Ethnic entrepreneurs request co-ethnic employees since the recruitment process is easier (it usually happens by word-of-mouth) and the necessary training is much easier since it is based on a shared cultural background (Wilson and Portes 1980; Waldinger 1986; Waldinger et al. 1990; Maxim 1992). Also in this case, the chance to hire employees is an important aspect that pulls immigrants towards entrepreneurship. Therefore it may be hypothesized that

H5: The more favourable it is to employ members of the ethnic group, the higher is the likelihood of creating ethnic ventures in the enclave.

Ethnic entrepreneurs may be inclined to create a new venture in the enclave and to identify as their main target other ethnic groups - for example the local people (Ram and Hillin 1994; Ram and Deakins 1996; Deakins et al. 1997; Pio 2007). If this happens, then ethnic entrepreneurs are interested in hiring employees who do not belong to the family of origin or their own ethnic group (Portes 1995) but to the local group of reference. The ability to communicate with others by speaking their own language is a very 
important aspect to leverage on in order to establish a trust-based relationship and to conclude a transaction. Being able to hire employees of other ethnic groups is a major opportunity on which the immigrant can leverage. Hence, we may hypothesise that

H6: The more favourable it is to employ members of other ethnic groups, the higher is the likelihood of creating ethnic ventures in the enclave.

Suppliers Generally speaking, when immigrants decide to create a new ethnic venture in the enclave, they offer an ethnic product. As highlighted by Chrysostome and Arcand (2009), by ethnic product we mean ethnic food, ethnic newspapers, ethnic clothes or ethnic goods. All the ethnic products are linked to the same culture shared by the entrepreneur, the potential customers and the effective suppliers. This is what Pio (2007) calls ethnicity. To guarantee the ethnicity of the products, ethnic entrepreneurs usually refer to ethnic suppliers who are inside the ethnic group and so are aware of the product most demanded by customers. The decision to refer to co-ethnic suppliers may also be due to informal credit policies. As noted by Walton-Roberts and Hiebert (1997), suppliers can extend credit with few concerns over repayment, since reputations are widely established and this can be a major advantage for ethnic entrepreneurs.

Suppliers of ethnic products can be members of the ethnic group who have moved to the destination country or they can still live in the country of origin. If the suppliers belong to the same ethnic group and they live in the destination country, business transactions are likely to have a very fast time-to-market and, above all, they are likely to be safe and successful because of the loyalty in the ethnic group (Wilson and Portes 1980). These are positive aspects that reduce the risk usually linked to business transactions and pull immigrants towards entrepreneurship. Thus, it is reasonable to hypothesise that

H7: The more favourable it is to purchase inputs from suppliers who are inside the ethnic group in the destination country, the higher is the likelihood of creating ethnic ventures in the enclave.

If the suppliers belong to the same ethnic group and live in the country of origin, entrepreneurs need to leverage on international support mechanisms (Portes and Bach 1985; Waldinger et al. 1990; Zhou 1995). These mechanisms, of course, are still safe and successful like those implemented with suppliers in the destination country since they all are trust-based. This is a very positive aspect that can pull immigrants towards entrepreneurial activities and, above all, can prevent local entrepreneurs from being in contact with the same ethnic suppliers. Accordingly, it is reasonable to hypothesise that

H8: The more favourable it is to purchase inputs from suppliers who are inside the ethnic group in the country of origin, the higher is the likelihood of creating ethnic ventures in the enclave.

Ethnic entrepreneurs can also pursue opportunities that derive from the economic context in the destination country by offering products that are not ethnic. This generally happens in those industries that native entrepreneurs do not consider so profitable. The lack of native entrepreneurs creates vacancies for ethnic entrepreneurs who can replace them - this is what Aldrich and Reiss (1976) and Waldinger et al. (1990) call ecological succession. As noted by Ma Mung (1992), it is very common to find ethnic 
entrepreneurs who buy non-ethnic products from local suppliers in order to satisfy customers from other ethnic groups or locals. The fact that immigrants can establish contact with local suppliers constitutes an opportunity on which they can leverage in order to become entrepreneurs. Thus, it is reasonable to hypothesise that

H9: The more favourable it is to purchase inputs from supplies belonging to other ethnic groups, the higher is the likelihood of creating ethnic ventures in the enclave.

Markets Prior evaluations of the size and characteristics of potential and actual markets are required to decide whether or not to create a new ethnic venture (Ram and Hillin 1994; Ram and Deakins 1996; Deakins et al. 1997; Ambrosini and Abbatecola 2002; Pio 2007). This decision is far from straightforward. Similarly to what happens in the mainstream market, assessment will concern the actual or potential market. Of course, in both cases, immigrants need to collect information about the ethnic community (Zhou 2004).

As regards the actual market, ethnic entrepreneurs can decide to sell their output to the members of the immigrant community itself (Waldinger et al. 1990) who already ask for them. If immigrants acknowledge, there is an already existing market, then the choice of whether or not to create a new venture is easy. Being in close contact with the existing market makes assessment of the market itself very easy and this can pull immigrants to be involved in entrepreneurship. Thus, it may be hypothesised that

H10: The more favourable it is to sell ethnic products to already existing ethnic markets, the higher is the likelihood of creating ethnic ventures in the enclave.

In reference to the potential market, evaluation is more complex (Waldinger et al. 1990). Ethnic entrepreneurs may realize that there is a certain demand for ethnic products from their co-ethnics but this demand is still unsatisfied. In this case, they have to create an ethnic market. Trust-based relationships are a good starting point but then ethnic entrepreneurs need to use business levers such as small credit policies, small gifts or special prices in order to make the demand grow (Waldinger et al. 1990). The main difficulty could be in assessing the quantity of products potentially required by co-ethnic members but the aspiring entrepreneur is supposed to know the ethnic network he belongs to. If evaluation is feasible, and hopefully it is positive, then immigrants are pulled towards entrepreneurship. So, it may be hypothesised that

H11: The more favourable it is to sell ethnic products to potential ethnic markets, the higher is the likelihood of creating ethnic ventures in the enclave.

As noted above, ethnic entrepreneurs can substitute entrepreneurs belonging to the native community or another group due to ecological succession (Aldrich and Reiss 1976; Waldinger et al. 1990). In other words, this means that native entrepreneurs seek opportunities in more profitable industries and thus give ethnic entrepreneurs the chance to replace them. Of course, the choice of which industry to enter is not arbitrary. Ethnic entrepreneurs, like all entrepreneurs in the broader sense, evaluate the potential market (Ram and Hillin 1994; Ram and Deakins 1996; Deakins et al. 1997; Pio 2007). They try and estimate the quantity of products demanded by potential customers (members of the native community or of another one) in order to establish whether or not it is worth launching a new entrepreneurial activity. If the results of 
estimations are encouraging, then immigrants are pulled towards entrepreneurship. Accordingly, it may be hypothesised that

H12: The more favourable it is to sell output to other ethnic groups, the higher is the likelihood of creating ethnic ventures in the enclave.

Institutional problems Generally speaking, institutions should help citizens in their own business activities and in entrepreneurship by providing assistance for the creation of new ventures (Baumol 1990; Gohmann et al. 2008). More specifically, in reference to ethnic entrepreneurship, institutions should offer various services like counselling, tax incentives and credit assistance programmes - although their relevance has been questioned (Maggioni et al. 1999) - to support immigrant involvement in entrepreneurship (Minniti 2008).

Reality is, however, different: institutions do not seem to favour immigrant involvement in entrepreneurship. Problems in communication - due to different languages - and difficulties in translating the required certificates are only some of the most common examples of bureaucratic barriers that can prevent immigrants from obtaining the necessary papers to create new ethnic ventures in the enclave. However, the emergence of bureaucratic or institutional problems (Sassen 1991; Daniels 1993; Daniels and Lever 1996) does not seem to discourage immigrants who can easily overcome them by leveraging on themselves - need for achievement and desire to be independent (Verheul et al. 2010) - or on their ethnic network. In both the cases, immigrants are pulled towards entrepreneurship by positive levers that seem to favour the pursuit of entrepreneurial opportunities. In this vein, it may be hypothesised that

H13: The more favourable it is to overcome institutional problems, the higher is the likelihood of creating ethnic ventures in the enclave.

Business model Ethnic entrepreneurs may decide to create a new venture in the enclave just by replicating a business model they already know. According to some scholars (Waldinger 1986; Waldinger et al. 1990; Chrysostome and Arcand 2009), immigrants seek to reproduce in the destination country a successful business model they already know by reducing or even avoiding the possible mistakes that can emerge. Of course, the possibility of replicating a business model is based on the assumption that the external context offers similar opportunities to pursue or, in other words, that the context is favourable to ethnic entrepreneurship. Therefore, it may be hypothesised that

H14: The more favourable it is to replicate a business model, the higher is the likelihood of creating ethnic ventures in the enclave.

Managerial competences As noted by Zhou (2004) and by Chrysostome and Arcand (2009), immigrants can learn and develop managerial competences which comprise the establishment of relationships with stakeholders, the allocation of human resources, adjustment to market demands and facilitation of communication within the organisation (Vinogradov and Isaken 2008). To explain how immigrants can develop managerial competences, Waldinger et al. (1990) provide a useful and very interesting example. Usually, in ethnic restaurants, a new employee can start working as dishwasher. Through learning by doing and observation, the newcomer can aspire to be a sandwich 
person, a cook or, eventually, to open his/her own restaurant. Generally speaking, ethnic entrepreneurs can improve their managerial competences by on-the-job training. In this vein, the context is assumed to be favourable to ethnic entrepreneurship and so it may be hypothesised that

H15: The more favourable it is to exploit managerial competences acquired on-thejob, the higher is the likelihood of creating ethnic ventures in the enclave.

As for methodological aspects, all the factors classified as pull are measured as a binary variable coded 0 if they are perceived as unfavourable in reference to the creation of ethnic ventures in the enclave and coded 1 if they are perceived as favourable.

\section{Push factors}

Push factors concern unemployment or unsatisfactory occupational status. These factors lead to direct identification of necessity entrepreneurs. This means that individuals view the possibility to become entrepreneurs as a response to dissatisfaction with their working conditions and thus they perceive the context they are in as negative.

Unemployment As stated above, immigrants who act as necessity ethnic entrepreneurs undergo exclusion from the labour market of the local community (Moore 1983). The main risk they have to face is unemployment. This may be due to discrimination from a local employer and to consequent exclusion from the mainstream labour market. Alternatively, it may be due to the perception that job offers in the mainstream labour market are unsuited to their skills and capabilities.

The state of unemployment and, above all, the consequent lack of requisites - like wages and lodgings - necessary to stay in the destination country (Wilson and Portes 1980; Light et al. 1994; Ram 1994; Phizacklea and Ram 1996; Kloosterman et al. 1998; Deakins 1999; Mata and Pendakur 1999; Johnson 2000; Drori et al. 2009) leads immigrants to perceive a negative context around them. As a consequence, the discouraging aspects mentioned above can push immigrants towards entrepreneurship. Indeed, the creation of a new ethnic venture in the enclave represents an escape that immigrants are compelled to evaluate. According to the above reasoning, it sounds reasonable to hypothesise that

H16: The less favourable is the situation associated with unemployment, the higher is the likelihood of creating ethnic ventures in the enclave.

Previous work In some contexts, immigrants can be included in the mainstream labour market but, because of their ethnicity, they can be discriminated against by local employers. Discrimination can take different forms: usually, it involves underpayment in relation to working hours, unsatisfactory assignments as regards the skills possessed, or unsuitable tasks in reference to the immigrant's education level (Min and Bozorgmehr 2003). According to Waldinger et al. (1990), the willingness to leave an underpaid, unsatisfactory, and unsuitable job can lead immigrants to view the creation of new ethnic ventures in the enclave as the only possible alternative. Therefore, it may be hypothesised that

H17: The less favourable are the working conditions related to the previous work, the higher is the likelihood of creating ethnic ventures in the enclave. 
As for methodological aspects, also in this case, all the factors classified as push are measured as a binary variable coded 0 if they are perceived as unfavourable in reference to the creation of ethnic ventures in the enclave and coded 1 if they are perceived as favourable.

\section{Socio-demographic factors}

The last category contains socio-demographic factors. This group of factors includes the housing area, age, the number of years spent in the destination country, level of education and gender. The nature of these factors is controversial. As stated above, if they are perceived as favourable, then they are included among pull factors and are useful to identify opportunity entrepreneurs. By contrast, if they are perceived as unfavourable, they are included among push factors and are helpful to identify necessity entrepreneurs.

Housing area According to Portes (1995), one of the main factors affecting ethnic entrepreneurship can be identified with the choice of living in the enclave or outside it. The ethnic social network developed in the enclave plays an important role among immigrants (Portes and Zhou 1992; Zhou 2004; Deakins et al. 2007; Katila and Wahlbeck 2011) since informal ties are stronger if the subjects involved are geographically close. Geographical proximity increases trust and reciprocal respect, verbal encouragement (Allen 2000) and, above all, emotional support (Min 1992; Martes 2000; Chrysostome and Arcand 2009). Emotional support emerges in reference to both problems and opportunities concerning private and working life. According to the above, if immigrants decide to live in the enclave then the possibility of meeting co-ethnic members can increase and this, in turn, can generate greater emotional support between the parties concerned. Such support can cover both the private and working spheres and can thus also play a critical role in creating new ethnic ventures in the enclave. Since immigrants are encouraged and supported in starting a new venture, it may be hypothesised that

H18a: The more favourable is the housing area, due to the decision to live in the enclave, the higher is the likelihood of creating ethnic ventures in the enclave.

Immigrants, of course, may be compelled to live outside the enclave, especially in order to reduce housing costs (Waldinger et al. 1990). Despite the economic benefit they can obtain, what is much more important is the relational sacrifice they have to undergo: by living outside the enclave, immigrants experience a sort of isolation from their ethnic group that may lead to dissatisfaction. Under such circumstances, creating an ethnic venture is a great challenge for immigrants. Hence, we may offer a rival hypothesis according to which

H18b: The less favourable is the housing area, due to the decision to live outside the enclave, the higher is the likelihood of creating ethnic ventures in the enclave.

As for methodological aspects, the housing variable is measured as a binary variable coded 0 if the ethnic entrepreneurs live outside the enclave and they perceive this choice as unfavourable, and coded 1 if the ethnic entrepreneurs live inside the enclave and they perceive the situation as favourable.

Age Another factor that can affect the creation of new ethnic ventures in the enclave is age. According to Reynolds et al. (2002) and to Shinnar and Young (2008), opportunity 
entrepreneurs are older than necessity entrepreneurs. In the enclave, co-ethnic members can use age as a primary parameter to evaluate whether or not to support aspiring entrepreneurs either informally (Johannisson 1993; Ram 1994; Kloosterman et al. 1998; Van Delf et al. 2000) or formally (Yoon 1995; Gold 2001; Guarnizo et al. 2003). Old immigrants are assumed to be better known - because of their previous working experience - than young immigrants. The trust-based support offered by co-ethnic members to old immigrants can be seen as a helpful situation to be exploited. It thus appears possible to hypothesize that

H19a: The more favourable is the situation that old immigrants perceive, the higher is the likelihood of creating ethnic ventures in the enclave.

Young immigrants experience the opposite situation (Shinnar and Young 2008). They are less well known by co-ethnic members - because they often have no previous working experience - and it is therefore harder to find co-ethnic members offering trustbased support. The scarce support they enjoy and the possible discrimination they undergo can be the main drivers pushing young immigrants towards entrepreneurship. Accordingly, it is reasonable to hypothesise that

H19b: The less favourable is the situation that young immigrants perceive, the higher is the likelihood of creating ethnic ventures in the enclave.

As for methodological aspects, the age variable is measured as a continuous variable transformed into a dummy according to the median value (40 years old). It is coded 0 if the ethnic entrepreneurs are younger than 40 years old and coded 1 if the entrepreneurs are 40 years old or more.

Years spent in the destination country Neither theoretical nor empirical previous studies show any kind of relationship between age and years spent in the destination country. Indeed, it is possible to find both old and young immigrants who have just moved to destination country or who have already been settled there for a long time. According to the above, the years spent in the destination country can be considered a stand-alone variable that allows us to inquire whether immigrants exploit an opportunity or face a state of necessity (Fregetto 2004; Volery 2007; Shinnar and Young 2008).

Unlike age, the number of years spent in the destination country defines immigrants' relationship with the local context rather than with the ethnic community (Volery 2007). Long stays in the destination country make immigrants familiar with the language of the country as well as local skills, customs and rules (Fregetto 2004). Thus, in the case of long stays in the destination country, immigrants are advantaged in creating new ethnic ventures. Hence, it seems reasonable to hypothesise that

H20a: The more favourable are the external circumstances that immigrants perceive due to long stays in the destination country, the higher is the likelihood of creating ethnic ventures in the enclave.

By contrast, staying little in the destination country means that immigrants are unlikely to be proficient in the destination country language, or they might not have necessary skills or be familiar with practices and rules. Thus, in the case of short stays in the destination country, immigrants are excluded from the mainstream labour market. As a consequence, they may come face to face with illicit activities or are pushed to consider entrepreneurship as an escape (Volery 2007). Thus, it is reasonable to hypothesise that 
H20b: The less favourable are the external circumstances that immigrants perceive due to short stays in the destination country, the higher is the likelihood of creating ethnic ventures in the enclave.

As for methodological aspects, the variable years spent in Italy is measured as a continuous variable that is transformed into a dummy according to the median value (10 years). It is coded 0 if the stay in Italy is shorter than 10 years, and 1 if the stay in Italy is 10 years or longer.

Level of education Another factor that can affect the creation of ethnic ventures in the enclave is the level of education (Waldinger et al. 1990; Johnson 2000; Min and Bozorgmehr 2000; Robb and Fairlie 2007; Shinnar and Young 2008). Previous studies show that the relationship between the level of education and the decision to start a new venture is not so obvious. On the one hand, some scholars, like Bates (1989) and Sequeira and Rasheed (2006), openly support the idea of a positive impact between the level of education and involvement in entrepreneurial activities. Hence, the higher is the level of education, the higher is the involvement in entrepreneurial activities: after achieving a high level of education, immigrants can look for several working alternatives, including the creation of a new ethnic venture. In line with the above reasoning, it is possible to hypothesise that

H21a: The more favourable are the working alternatives that immigrants can evaluate because of a high education level, the higher is the likelihood of creating ethnic ventures in the enclave.

On the other hand, some scholars point out that the level of education can be a barrier to entrepreneurial activity. Christopher (1998) and Volery (2007), for example, maintain that ethnic entrepreneurs seek entry to markets where the level of education does not represent an entry barrier. Very often, immigrants with a low level of education are driven towards entrepreneurship by a state of necessity. According to this, it may be hypothesised that

H21b: The less favourable are the working alternatives that immigrants can evaluate because of a low education level, the higher is the likelihood of creating ethnic ventures in the enclave.

As for methodological aspects, the variable level of education is measured as a discrete variable that is transformed into dummy according to the median value (primary school). It is coded 0 if ethnic entrepreneurs attended primary school and it is coded 1 if ethnic entrepreneurs attended high school or university.

Gender Generally speaking, since entrepreneurship has always been considered an activity for men, female entrepreneurship has been considered a limited phenomenon (Buttner and Moore 1997; Moore and Rickel 1980). Several scholars (Kalleberg and Leitch 1991; Fischer et al. 1993; Anna et al. 1999; Brush et al. 2001; Wagner 2005; Giacomin et al. 2007; Clark and Drinkwater 2010) have underlined the fact that women are expected to be less inclined towards entrepreneurship than men because of the segregation they usually undergo. In reference to ethnic entrepreneurship, this appears even truer: many cultures do not accept that women can work and they do not even conceive of the possibility that women can become entrepreneurs. This 
means that men can get a sort of support if they aspire to become entrepreneurs but women cannot. As a consequence, men perceive the context they are in as favourable since they are allowed to become entrepreneurs - while women feel the context around them is unfavourable - since they are impeded from becoming entrepreneurs. Thus, two rival hypotheses are presented:

H22a: The more favourable is the gender-related treatment usually reserved for males, the higher is the likelihood of creating ethnic ventures in the enclave.

H22b: The less favourable is the gender-related treatment usually reserved for females, the higher is the likelihood of creating ethnic ventures in the enclave.

As for methodological aspects, the gender variable is measured as a binary variable coded 0 if the ethnic entrepreneur is female and coded 1 if the ethnic entrepreneur is male.

\section{Research methods}

\section{Defining the population and the context to inquire}

The present study relies on data obtained through a questionnaire survey administered to a sample of fifty Ukrainian entrepreneurs in Caserta, one of the municipalities in Campania, a region in southern Italy. The decision to focus on Ukrainian entrepreneurs in Caserta is due to the importance achieved by ethnic entrepreneurship in the area and by the ethnic group in question (Matricano 2011b). According to the report Immigratimprenditori in Italia published by Fondazione Ethnoland 2009 (the last edition available when the research project was planned) there are 165,114 ventures founded by immigrants in Italy. Their Italy-wide distribution is not uniform (see Table 1): regions like Lombardy, Emilia Romagna, Piedmont, Tuscany, Veneto and Lazio seem to be the best contexts to start new ethnic ventures. Other regions, like Umbria, Valle d'Aosta, Basilicata and Molise do not. Since Campania ranks seventh in the list, it is a prolific context for ethnic ventures.

Several differences arise from the municipalities included in Campania so it was resolved to focus on just one of the municipalities. To do this, data on the distribution of immigrant ventures in the municipalities in Campania were examined (Table 2). The total number of immigrant ventures in Campania is 4,222.

The above-cited data help to clarify why the questionnaire survey was conducted in Caserta: this is the municipality that shows the highest percentage (55\%) of ethnic ventures in Campania. As for the ethnic group to be interviewed, the choice is based on data provided by the XX Rapporto Caritas-Migrantes, Dossier Statistico 2010 (the latest edition available when the research project was planned). The total number of immigrants in Campania is 147,057, and may be classified as follows (Table 3) according to country of origin.

As may be noted, the Ukrainian community is the most numerous in Campania, which justifies the choice to analyze it. By combining the official data about immigrants and their ventures, the choice to focus on Ukrainian entrepreneurs in Caserta appears much more than reasonable.

\section{Data collection and descriptive statistics}

After deciding to focus on Ukrainian entrepreneurs in Caserta, we proceeded with sample selection. According to the report Immigratimprenditori in Italia published by 
Table 1 Distribution of ventures founded by immigrants Italy-wide

\begin{tabular}{lc}
\hline Italian regions & Number of ethnic ventures \\
\hline Lombardy & 37,147 \\
Emilia Romagna & 20,316 \\
Piedmont & 19,083 \\
Tuscany & 18,933 \\
Veneto & 18,289 \\
Lazio & 17,321 \\
Sicily & 4,962 \\
Campania & 4,222 \\
Marche & 4,059 \\
Friuli Venezia Giulia & 3,710 \\
Liguria & 3,610 \\
Calabria & 3,514 \\
Abruzzo & 2,924 \\
Trentino Alto Adige & 2,256 \\
Sardinia & 2,150 \\
Puglia & 1,612 \\
Umbria & 479 \\
Valle d'Aosta & 246 \\
Basilicata & 154 \\
Tolise & 127 \\
\hline Soul & 165,114 \\
\hline S & \\
\hline
\end{tabular}

Source: Immigratimprenditori in Italia edited by Fondazione Ethnoland 2009.

Fondazione Ethnoland 2009, there are 105 ventures founded by Ukrainian entrepreneurs in Campania. By mixing these data with those in the XX Rapporto Caritas-Migrantes, Dossier Statistico 2010, there are nearly 60 Ukrainian ventures based in Caserta. Key informants working in the Municipality Authority of Caserta have confirmed this number.

Through the same key informants and thanks to word-of-mouth, a sample of 50 Ukrainian entrepreneurs in Caserta was identified, which appears to be highly representative of the category in question. Since some immigrants provided unclear answers, 42 questionnaires out of the administered 50 were considered valid. After collecting and recording data, we proceeded with the descriptive statistics that are a first step towards identifying the determinants affecting the creation of Ukrainian ventures in the enclave in Caserta (Table 4).

Table 2 Distribution of immigrant ventures in Campania municipalities

\begin{tabular}{lc}
\hline Municipalities & Percentage of immigrant ventures (\%) \\
\hline Avellino & 3.2 \\
Benevento & 2.2 \\
Caserta & 55.1 \\
Naples & 27.5 \\
Salerno & 12 \\
Total & 100 \\
\hline
\end{tabular}

Source: Immigratimprenditori in Italia published by Fondazione Ethnoland 2009. 
Table 3 Distribution of immigrants in Campania according to country of origin

\begin{tabular}{lc}
\hline Country of origin & Number of immigrants \\
\hline Ukraine & 33,238 \\
Romania & 24,163 \\
Morocco & 12,267 \\
Poland & 10,763 \\
China & 7,698 \\
Albania & 6,326 \\
Sri Lanka & 6,006 \\
Bulgaria & 4,342 \\
Algeria & 2,953 \\
Tunisia & 2,943 \\
Philippines & 2,858 \\
Russia & 2,161 \\
Nigeria & 2,127 \\
India & 1,764 \\
Senegal & 1,658 \\
Bangladesh & 1,517 \\
Brazil & 1,493 \\
Moldavia & 1,382 \\
Germany & 1,270 \\
Other countries & 20,128 \\
Total & 147,057 \\
\hline Source: $x x$ Rappoto & \\
\hline
\end{tabular}

Source: XX Rapporto Caritas-Migrantes, Dossier Statistico 2010.

First of all, attention is paid to the creation of ethnic ventures in the enclave - the dependent variable in the model. According to evidence provided, $73.8 \%$ of the interviewees created their ethnic venture in the enclave.

With regard to the descriptive statistics concerning pull factors, in terms of sources of capital, the results are very clear. All the interviewees stated they had invested capital of their own or that of their family (100\%). A few of them had received capital from members of the same ethnic group (4.8\%). None of the Ukrainian entrepreneurs used capital loaned by local banks.

In terms of employee nationality, very few Ukrainian entrepreneurs employed members of their family (4.8\%) or of their ethnic group (40.5\%). None of the Ukrainian entrepreneurs in Caserta stated that they took on employees of different ethnic groups.

With reference to the markets for buying inputs, it is important to state that entrepreneurs offering services are not included. Hence, the results refer to 22 entrepreneurs dealing with manufacturing, processing and selling of products. However, it emerges that more than half of the sample acquires inputs from the country of origin (54.6\%) and that few of the interviewees buy inputs from other members of the ethnic group in Italy (13.6\%). Just less than one-third of the sample (31.8\%) acquires inputs from different ethnic groups, especially from Italian suppliers.

With reference to the market for selling outputs, nearly all the entrepreneurs of the sample sell their products/services to the Ukrainian community in Caserta (97.6\%). More than half the sample $(57.1 \%)$ stated that the idea to create a new venture 
Dependent variable

*Since all the variables are binary, the table shows only the percentage of answers associated to YES (code 1); Source: Questionnaire survey.

depended on the potential demand for ethnic goods/services. Many of the Ukrainian entrepreneurs (80.5\%) sell their products/services to other ethnic groups, too, Italians included.

The interviewees asserted that they could easily overcome the difficulties linked to bureaucratic procedures, i.e. papers to dispatch or permission to be obtained from local government $(85.7 \%)$. More than half of the sample (52.4\%) wanted to replicate a business model already tested while $21.4 \%$ wanted to exploit competences acquired on-the-job.

As for push factors, $64.3 \%$ of the sample were driven to create a new venture to get out of unemployment while $7.1 \%$ was motivated by the possibility to leave their previous work.

Finally, in terms of socio-demographic factors, $45.2 \%$ stated they live in the Ukrainian enclave. As for age, $47.6 \%$ of them are 40 years old or over and $52.4 \%$ are younger; $66.7 \%$ out of the sample had been living in Italy for more than 10 years. As for the level of education, $71.4 \%$ had a high school certificate or higher (degree, $\mathrm{PhD}$ ). Finally, as for gender, most of the sample (71.4\%) was made up of male entrepreneurs. 


\section{Results}

\section{The results of the logistic regression}

At this stage, more research is needed in order to investigate whether pull or push factors affect Ukrainian entrepreneurship in Caserta. Different statistical methods (connections matrix and logistic regression model) are applied in reference to the creation of ethnic ventures in the Ukrainian enclave in Caserta (Table 5).

Further investigations of the variables and their connections provided no indication of multicollinearity among the predictor variables. Thus, in order to determine the factors affecting the creation of ethnic ventures in the enclave, a logistic regression model was used. The basic model that was estimated is

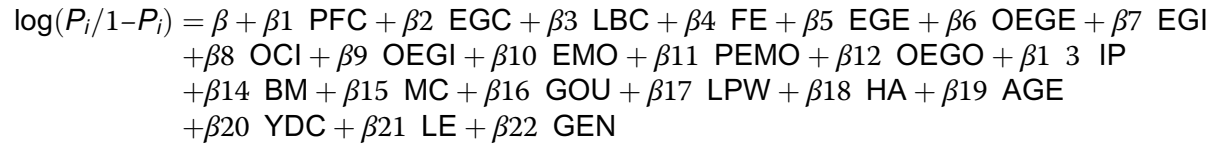

where $\beta i(i=0, \ldots, 22)$ are the coefficients and the independent variable is $\log \left(P_{i} / 1-P_{i}\right)$, i.e. the logarithm of the ratio of the probability that a Ukrainian immigrant in Caserta has created an ethnic venture in the enclave relative to the probability that the same Ukrainian immigrant has not created an ethnic venture in the enclave.

By using a forward Wald approach, our results show that only two factors are statistically significant, namely housing area and age (Table 6). Some variables (saved capital, capital rent from local banks or different sources and employees from other ethnic groups) are constant in the model and are therefore automatically excluded when proceeding with logistic regression.

As may be noted in Table 6, the equation has good predictive power, with $88.1 \%$ of correct predictions. The value of Nagelkerke $R^{2}$ (pseudo $R^{2}$ ) is 0.316 , which is reasonable for qualitative dependent variable models. Furthermore, the computed value of the likelihood ratio (10.064) is much larger than the critical value of the chi-squared statistics with two degrees of freedom at the $5 \%$ level. As a result, the null hypothesis, based on the assumption that all the parameter coefficients are zeros, is strongly rejected and hence the model is significant.

Based on the above results, the creation of ethnic ventures in the Ukrainian enclave in Caserta is affected by

1. Housing area: The Ukrainians who do not live in their enclave show a higher probability of creating a new venture in the enclave than those living in the enclave (the coefficient $\beta$ for housing area is 0.130 ).

2. Age: The Ukrainians who are younger than 40 years old show a higher probability of creating a new venture in the enclave than those over 40 years old (the coefficient $\beta$ for age is 0.146 ).

In sum, none of the factors that are included in the group of pull and push factors affect the choice to start an ethnic venture in the enclave. Two of the socio-demographic factors living outside the enclave and being younger than 40 - do that. In line with the rationales presented above, these results show that Ukrainian entrepreneurs perceive the context around them as negative. The choice to live outside the enclave and the fact of being younger than 40 years old are seen as unfavourable motivations and are thus ascribed to push 
Table 5 Connections matrix

\begin{tabular}{|c|c|c|c|c|c|c|c|c|c|c|c|c|c|c|c|c|c|c|c|c|}
\hline & & EGC & $\mathrm{FE}$ & EGE & EGI & $\mathrm{OCl}$ & OEGI & EMO & PEMO & OEGO & IP & BM & MC & GOU & LPW & HA & AGE & YDC & $\mathrm{LE}$ & GEN \\
\hline $\mathrm{H} 2$ & EGC & 1 & & & & & & & & & & & & & & & & & & \\
\hline $\mathrm{H} 4$ & $\mathrm{FE}$ & $\begin{array}{c}9.476 \\
(0.002)^{*}\end{array}$ & 1 & & & & & & & & & & & & & & & & & \\
\hline $\mathrm{H} 5$ & EGE & $\begin{array}{c}3.088 \\
(0.079)\end{array}$ & $\begin{array}{l}3.088 \\
(.079)\end{array}$ & 1 & & & & & & & & & & & & & & & & \\
\hline $\mathrm{H} 7$ & EGl & $\begin{array}{c}27.3 \\
(0.000)^{*}\end{array}$ & $\begin{array}{c}5.815 \\
(0.016)^{* *}\end{array}$ & $\begin{array}{c}0.920 \\
(0.338)\end{array}$ & 1 & & & & & & & & & & & & & & & \\
\hline $\mathrm{H} 8$ & $\mathrm{OCl}$ & $\begin{array}{c}5.25 \\
(0.022)^{* *}\end{array}$ & $\begin{array}{c}0.473 \\
(0.492)\end{array}$ & $\begin{array}{c}0.632 \\
(0.426)\end{array}$ & $\begin{array}{c}2.297 \\
(0.130)\end{array}$ & 1 & & & & & & & & & & & & & & \\
\hline $\mathrm{H} 9$ & OEGl & $\begin{array}{c}10.5 \\
(0.001)^{*}\end{array}$ & $\begin{array}{c}1.68 \\
(0.195)\end{array}$ & $\begin{array}{c}0.968 \\
(0.325)\end{array}$ & $\begin{array}{c}5.815 \\
(0.016)^{* *}\end{array}$ & $\begin{array}{c}0.840 \\
(0.359)\end{array}$ & 1 & & & & & & & & & & & & & \\
\hline $\mathrm{H} 10$ & EMO & $\begin{array}{c}0.105 \\
(0.746)\end{array}$ & $\begin{array}{c}0.105 \\
(0.746)\end{array}$ & $\begin{array}{c}3.088 \\
(0.079)\end{array}$ & $\begin{array}{c}0.162 \\
(0.688)\end{array}$ & $\begin{array}{c}0.840 \\
(0.359)\end{array}$ & $\begin{array}{c}0.420 \\
(0.517)\end{array}$ & 1 & & & & & & & & & & & & \\
\hline $\mathrm{H} 11$ & PEMO & $\begin{array}{c}2.80 \\
(0.094)\end{array}$ & $\begin{array}{c}2.80 \\
(0.094)\end{array}$ & $\begin{array}{c}0.206 \\
(0.650)\end{array}$ & $\begin{array}{c}0.748 \\
(0.387)\end{array}$ & $\begin{array}{c}2.188 \\
(0.139)\end{array}$ & $\begin{array}{c}0.700 \\
(0.403)\end{array}$ & $\begin{array}{c}0.044 \\
(0.834)\end{array}$ & 1 & & & & & & & & & & & \\
\hline $\mathrm{H} 12$ & OEGO & $\begin{array}{c}0.573 \\
(0.449)\end{array}$ & $\begin{array}{c}0.573 \\
(0.449)\end{array}$ & $\begin{array}{c}4.1 \\
(0.043)^{* *}\end{array}$ & $\begin{array}{c}0.881 \\
(0.348)\end{array}$ & $\begin{array}{c}1.414 \\
(0.234)\end{array}$ & $\begin{array}{c}0.255 \\
(0.614)\end{array}$ & $\begin{array}{c}1.018 \\
(0.313)\end{array}$ & $\begin{array}{c}0.424 \\
(0.515)\end{array}$ & 1 & & & & & & & & & & \\
\hline $\mathrm{H} 13$ & IP & $\begin{array}{c}0.350 \\
(0.554)\end{array}$ & $\begin{array}{c}0.350 \\
(0.554)\end{array}$ & $\begin{array}{c}0.264 \\
(0.608)\end{array}$ & $\begin{array}{c}0.538 \\
(0.463)\end{array}$ & $\begin{array}{c}0.486 \\
(0.486)\end{array}$ & $\begin{array}{c}1.400 \\
(0.237)\end{array}$ & $\begin{array}{c}0.350 \\
(0.554)\end{array}$ & $\begin{array}{c}5.250 \\
(0.022)^{* *}\end{array}$ & $\begin{array}{c}0.094 \\
(0.759)\end{array}$ & 1 & & & & & & & & & \\
\hline $\mathrm{H} 14$ & BM & $\begin{array}{c}0.005 \\
(0.945)\end{array}$ & $\begin{array}{c}0.005 \\
(0.945)\end{array}$ & $\begin{array}{c}0.475 \\
(0.491)\end{array}$ & $\begin{array}{c}0.264 \\
(0.607)\end{array}$ & $\begin{array}{c}0.038 \\
(0.845)\end{array}$ & $\begin{array}{c}0.305 \\
(0.580)\end{array}$ & $\begin{array}{c}0.005 \\
(0.945)\end{array}$ & $\begin{array}{c}0.072 \\
(0.789)\end{array}$ & $\begin{array}{c}0.046 \\
(0.830)\end{array}$ & $\begin{array}{c}0.573 \\
(0.449)\end{array}$ & 1 & & & & & & & & \\
\hline $\mathrm{H} 15$ & $M C$ & $\begin{array}{c}0.573 \\
(0.449)\end{array}$ & $\begin{array}{c}0.573 \\
(0.449)\end{array}$ & $\begin{array}{c}0.075 \\
(0.784)\end{array}$ & $\begin{array}{c}0.881 \\
(0.348)\end{array}$ & $\begin{array}{c}0.226 \\
(0.634)\end{array}$ & $\begin{array}{c}0.255 \\
(0.614)\end{array}$ & $\begin{array}{c}0.573 \\
(0.449)\end{array}$ & $\begin{array}{c}0.012 \\
(0.914)\end{array}$ & $\begin{array}{c}0.004 \\
(0.948)\end{array}$ & $\begin{array}{c}0.094 \\
(0.759)\end{array}$ & $\begin{array}{c}6.121 \\
(0.013)^{* *}\end{array}$ & 1 & & & & & & & \\
\hline $\mathrm{H} 16$ & GOU & $\begin{array}{c}1.167 \\
(0.280)\end{array}$ & $\begin{array}{c}1.167 \\
(0.280)\end{array}$ & $\begin{array}{c}0.371 \\
(0.542)\end{array}$ & $\begin{array}{c}1.795 \\
(0.180)\end{array}$ & $\begin{array}{c}3.744 \\
(0.053)^{* * *}\end{array}$ & $\begin{array}{c}0.187 \\
(0.666)\end{array}$ & $\begin{array}{c}1.167 \\
(0.280)\end{array}$ & $\begin{array}{c}4.978 \\
(0.026)^{* *}\end{array}$ & $\begin{array}{c}0.908 \\
(0.341)\end{array}$ & $\begin{array}{c}2.921 \\
(0.087)\end{array}$ & $\begin{array}{c}0.543 \\
(0.461)\end{array}$ & $\begin{array}{c}4.780 \\
(0.029)^{* *}\end{array}$ & 1 & & & & & & \\
\hline $\mathrm{H} 17$ & LPW & $\begin{array}{c}5.815 \\
(0.016)^{* *}\end{array}$ & $\begin{array}{c}5.815 \\
(0.016)^{* *}\end{array}$ & $\begin{array}{c}0.920 \\
(0.338)\end{array}$ & $\begin{array}{c}3.341 \\
(0.068)\end{array}$ & $\begin{array}{c}0.036 \\
(0.850)\end{array}$ & $\begin{array}{c}0.646 \\
(0.421)\end{array}$ & $\begin{array}{c}5.185 \\
(0.016)^{* *}\end{array}$ & $\begin{array}{c}0.748 \\
(0.387)\end{array}$ & $\begin{array}{c}0.881 \\
(0.348)\end{array}$ & $\begin{array}{c}0.538 \\
(0.463)\end{array}$ & $\begin{array}{c}0.264 \\
(0.607)\end{array}$ & $\begin{array}{c}0.272 \\
(0.602)\end{array}$ & $\begin{array}{c}0.008 \\
(0.929)\end{array}$ & 1 & & & & & \\
\hline $\mathrm{H} 18$ & $\mathrm{HA}$ & $\begin{array}{c}0.019 \\
(0.890)\end{array}$ & $\begin{array}{l}2.542 \\
(0.111)\end{array}$ & $\begin{array}{c}0.190 \\
(0.663)\end{array}$ & $\begin{array}{c}0.599 \\
(0.439)\end{array}$ & $\begin{array}{c}1.163 \\
(0.281)\end{array}$ & $\begin{array}{c}0.481 \\
(0.488)\end{array}$ & $\begin{array}{c}0.019 \\
(0.890)\end{array}$ & $\begin{array}{c}0.513 \\
(0.474)\end{array}$ & $\begin{array}{c}0.003 \\
(0.957)\end{array}$ & $\begin{array}{c}4.00 \\
(0.527)\end{array}$ & $\begin{array}{c}0.349 \\
(0.554)\end{array}$ & $\begin{array}{c}0.003 \\
(0.957)\end{array}$ & $\begin{array}{c}2.052 \\
(0.152)\end{array}$ & $\begin{array}{c}0.185 \\
(0.667)\end{array}$ & 1 & & & & \\
\hline
\end{tabular}


Table 5 Connections matrix (Continued)

\begin{tabular}{|c|c|c|c|c|c|c|c|c|c|c|c|c|c|c|c|c|c|c|c|c|}
\hline $\mathrm{H} 19$ & AGE & $\begin{array}{c}2.31 \\
(0.129)\end{array}$ & $\begin{array}{c}0.005 \\
(0.945)\end{array}$ & $\begin{array}{c}0.004 \\
(0.952)\end{array}$ & $\begin{array}{c}0.470 \\
(0.493)\end{array}$ & $\begin{array}{l}2.444 \\
(0.118)\end{array}$ & $\begin{array}{c}0.076 \\
(0.782)\end{array}$ & $\begin{array}{c}0.005 \\
(0.945)\end{array}$ & $\begin{array}{c}0.795 \\
(0.372)\end{array}$ & $\begin{array}{c}0.289 \\
(0.591)\end{array}$ & $\begin{array}{c}0.016 \\
(0.900)\end{array}$ & $\begin{array}{c}7.832 \\
(0.005)^{*}\end{array}$ & $\begin{array}{c}0.046 \\
(0.830)\end{array}$ & $\begin{array}{c}0.543 \\
(0.461)\end{array}$ & $\begin{array}{c}0.470 \\
(0.493)\end{array}$ & $\begin{array}{c}0.423 \\
(0.516)\end{array}$ & 1 & & & \\
\hline $\mathrm{H} 2 \mathrm{O}$ & YDC & $\begin{array}{c}1.05 \\
(0.306)\end{array}$ & $\begin{array}{c}0.263 \\
(0.608)\end{array}$ & $\begin{array}{c}1.235 \\
(0.266)\end{array}$ & $\begin{array}{c}0.000 \\
(1.000)\end{array}$ & $\begin{array}{c}4.725 \\
(0.030)^{* *}\end{array}$ & $\begin{array}{c}0.343 \\
(0.558)\end{array}$ & $\begin{array}{c}1.050 \\
(0.306)\end{array}$ & $\begin{array}{c}1.750 \\
(0.186)\end{array}$ & $\begin{array}{c}0.000 \\
(1.000)\end{array}$ & $\begin{array}{c}0.875 \\
(0.350)\end{array}$ & $\begin{array}{c}0.764 \\
(0.382)\end{array}$ & $\begin{array}{c}0.000 \\
(1.000)\end{array}$ & $\begin{array}{c}0.467 \\
(0.495)\end{array}$ & $\begin{array}{c}1.615 \\
(0.204)\end{array}$ & $\begin{array}{c}0.192 \\
(0.661)\end{array}$ & $\begin{array}{l}13.793 \\
(0.000)^{*}\end{array}$ & 1 & & \\
\hline $\mathrm{H} 21$ & LE & $\begin{array}{c}0.840 \\
(0.359)\end{array}$ & $\begin{array}{c}0.840 \\
(0.359)\end{array}$ & $\begin{array}{c}0.632 \\
(0.426)\end{array}$ & $\begin{array}{c}1.292 \\
(0.256)\end{array}$ & $\begin{array}{c}1.167 \\
(0.280)\end{array}$ & $\begin{array}{c}0.000 \\
(1.000)\end{array}$ & $\begin{array}{c}0.473 \\
(0.492)\end{array}$ & $\begin{array}{c}0.010 \\
(0.921)\end{array}$ & $\begin{array}{c}4.582 \\
(0.032)^{* *}\end{array}$ & $\begin{array}{c}0.078 \\
(0.780)\end{array}$ & $\begin{array}{c}0.239 \\
(0.625)\end{array}$ & $\begin{array}{c}0.127 \\
(0.721)\end{array}$ & $\begin{array}{c}0.259 \\
(0.611)\end{array}$ & $\begin{array}{l}2.297 \\
(0.130)\end{array}$ & $\begin{array}{l}2.778 \\
(0.096)\end{array}$ & $\begin{array}{c}0.773 \\
(0.379)\end{array}$ & $\begin{array}{l}2.100 \\
(0.147)\end{array}$ & 1 & \\
\hline $\mathrm{H} 22$ & GEN & $\begin{array}{c}0.84 \\
(0.359)\end{array}$ & $\begin{array}{c}0.84 \\
(0.359)\end{array}$ & $\begin{array}{c}1.670 \\
(0.196)\end{array}$ & $\begin{array}{c}1.292 \\
(0.256)\end{array}$ & $\begin{array}{c}1.167 \\
(0.280)\end{array}$ & $\begin{array}{c}3.36 \\
(0.067)\end{array}$ & $\begin{array}{c}0.840 \\
(0.359)\end{array}$ & $\begin{array}{c}0.350 \\
(0.554)\end{array}$ & $\begin{array}{c}0.226 \\
(0.634)\end{array}$ & $\begin{array}{c}0.078 \\
(0.780)\end{array}$ & $\begin{array}{c}0.038 \\
(0.845)\end{array}$ & $\begin{array}{c}0.226 \\
(0.634)\end{array}$ & $\begin{array}{c}0.041 \\
(0.839)\end{array}$ & $\begin{array}{c}0.036 \\
(0.850)\end{array}$ & $\begin{array}{c}0.086 \\
(0.769)\end{array}$ & $\begin{array}{c}0.239 \\
(0.625)\end{array}$ & $\begin{array}{c}0.525 \\
(0.469)\end{array}$ & $\begin{array}{c}1.412 \\
(0.235)\end{array}$ & 1 \\
\hline
\end{tabular}

Constant independent variables excluded from the model: $\mathrm{H} 1$ - Start-up capital personally saved or loaned by family members (PFC); H3 - Start-up capital loaned by local banks (LBC); H6 - Employees belonging to other ethnic groups (OEGE). * $p<0.01 ;{ }^{* *} p<0.05 ;{ }^{* * *} p<0.1$. 


\begin{tabular}{|c|c|c|}
\hline \multirow[t]{2}{*}{ Independent variables } & \multicolumn{2}{|c|}{$\begin{array}{l}\text { Dependent variable: ethnic } \\
\text { venture in the enclave }\end{array}$} \\
\hline & Coefficients $(\beta)$ & $p$ value \\
\hline Intercept & 25.094 & 0.001 \\
\hline \multicolumn{3}{|l|}{ Pull factors } \\
\hline H1: Start-up capital personally saved or loaned by family members (PFC) & Constant & Constant \\
\hline H2: Start-up capital loaned by members of the ethnic group (EGC) & 0.033 & 0.855 \\
\hline H3: Start-up capital loaned by local banks (LBC) & Constant & Constant \\
\hline H4: Employees belonging to the family (FE) & 0.022 & 0.883 \\
\hline H5: Employees belonging to the ethnic group (EGE) & 0.399 & 0.527 \\
\hline H6: Employees belonging to other ethnic groups (OEGE) & Constant & Constant \\
\hline H7: Ethnic inputs from the ethnic group in the destination country (EGI) & 0.032 & 0.859 \\
\hline H8: Ethnic inputs from the ethnic group in the origin country $(\mathrm{OCl})$ & 0.074 & 0.785 \\
\hline H9: Inputs from other ethnic groups (OEGI) & 0.025 & 0.874 \\
\hline H10: Ethnic outputs to already existing ethnic markets (EMO) & 0.341 & 0.559 \\
\hline H11: Ethnic outputs to potential ethnic markets (PEMO) & 0.846 & 0.358 \\
\hline H12: Outputs to other ethnic groups (OEGO) & 0.280 & 0.596 \\
\hline H13: Institutional problems (IP) & 1.804 & 0.179 \\
\hline H14: Business model (BM) & 0.278 & 0.598 \\
\hline H15: Managerial competences (MC) & 0.010 & 0.920 \\
\hline \multicolumn{3}{|l|}{ Push factors } \\
\hline H16: Unemployment (GOU) & 1.054 & 0.305 \\
\hline H17: Previous work (LPW) & 0.012 & 0.911 \\
\hline \multicolumn{3}{|l|}{ Socio-demographic factors } \\
\hline H18: Housing area (HA) & 0.130 & $0.021^{* *}$ \\
\hline H19: Age (AGE) & 0.146 & $0.030^{* *}$ \\
\hline H2O: Number of years spent in the destination country (YDC) & 0.010 & 0.920 \\
\hline H21: Level of education (LE) & 0.619 & 0.431 \\
\hline H22: Gender (GEN) & 0.017 & 0.896 \\
\hline
\end{tabular}

Number of cases $=42$; chi-square of Omnibus test $(d f)=10.064(2)$; Nagelkerke $R^{2}$ (pseudo $\left.R^{2}\right)=0.316$; percentage of correct predictions $=88.1 \% ;{ }^{*} p<0.01 ;{ }^{* *} p<0.05 ;{ }^{* * *} p<0.1$.

factors. Accordingly, it seems reasonable to assume that the Ukrainians in Caserta are necessity entrepreneurs.

\section{Discussion and conclusion}

The present paper investigated the factors that can affect the immigrants' choice to create a new venture in the enclave in order to test whether the Ukrainians in Caserta are opportunity or necessity entrepreneurs and to clarify how immigrants perceive the context around them. According to statistical elaborations only two socio-demographic factors affect the immigrant's choice to create a new venture in the enclave: housing area and age. As already stated, the Ukrainians show a higher probability of creating a new venture in the enclave if they do not live in their enclave and are younger than 40 years old. 
Some insights may be gleaned from reflecting on the above results: Ukrainian entrepreneurs seem to undergo both social exclusion and discrimination on the part of their ethnic group. Social exclusion is evident in reference to the housing area. As anticipated, by living in the enclave, immigrants support each other through reciprocal respect, verbal encouragement and emotional support. However, according to our findings, the Ukrainians who decide to create a venture in the enclave live outside the enclave. They cannot leverage on the ethnic network they belong to and hence the creation of a new ethnic venture in the enclave becomes a challenge.

Instead, discrimination results from age. As noted in the associated rationale, since older immigrants have previous working experience, it is easier for them to get trust-based support from their ethnic group; for young immigrants, it works the other way round. The latter seem to receive scant trust-based support from their ethnic group due to their non-existent or limited working experience. As a result, because of the discrimination experienced, young immigrants are probably pushed to create ethnic ventures in the enclave rather than pulled.

As a consequence of both exclusion and discrimination, the choice to create an ethnic venture can be explained by recalling the theory proposed by Ambrosini (2000), termed 'social promotion'. According to the above scholar and others who share this view (Pécoud 2004; Volery 2007; de Haas 2010; Giacomin et al. 2011), the creation of an ethnic venture in the enclave is just a means to be noticed and appreciated by members of the ethnic and local communities (see also Elmlund 2005).

This finding would appear of considerable interest to policy makers who - in order to achieve the social and economic advantages linked to ethnic entrepreneurship, as underlined above - are continually looking for tools and actions able to support and foster the creation of new ethnic ventures in the enclave. Policy makers can evaluate two alternatives: they can try to make immigrants change the way they perceive entrepreneurship by moving them from necessity to opportunity entrepreneurs, or they can decide to support ethnic entrepreneurship as it is by exploiting necessity entrepreneurship. In the former case, policy makers could try to encourage ethnic networking. By developing and supporting the networking activity - not only in reference to the housing area but also in reference to the relationship with customers, suppliers, employers, service providers and so on increasing numbers of entrepreneurial opportunities can emerge. As a consequence, immigrants could perceive the creation of an ethnic venture in the enclave not as a challenge but as an alternative able to satisfy personal and working ambitions. Ethnic ventures could then be created in different industries - even in knowledge or capital-intensive industries - and could aim chiefly at growth. If this were to happen, both economic and occupational advantages would then be derived.

In the latter case, i.e. by supporting entrepreneurship as it is, policy makers could develop synergies between immigrants and local institutions in order to supply more information about counselling programmes, tax incentives and credit assistance (if any) in order to push immigrants towards entrepreneurship even more. In this vein, immigrants who are not really engaged in entrepreneurship (as necessity entrepreneurs usually are) could be attracted by the ease of creating a new venture and hence economic and occupational advantages could be achieved as well. 
At this point, some limitations of our study need to be addressed. In particular, two would appear substantive. First of all, our study is based on cross-sectional data since the respondents operate in different industries. As is well known, each industry has specific dynamics that would require an idiosyncratic approach. Thus, according to the different industries we consider, some differences in the entrepreneurial approach inevitably occur, but in the present study, they were not taken into account. The second limitation deals with the peculiarities of the ethnic group and of the local context that prevent the achieved results from being generalised. These results, in fact, are only representative of Ukrainian entrepreneurs in Caserta and do not allow for any type of generalisation.

According to the above limitations, future research could address several paths. An interesting research strand could be to focus on specific industries in order to highlight the factors affecting the creation of new ethnic ventures in a specific industry. Another interesting avenue to pursue could aim to identify and compare the factors affecting entrepreneurial involvement by the same ethnic group in different municipalities or in the same municipality by different ethnic groups. The first suggestion could yield interesting results about the entrepreneurial approach of a specific ethnic group. The second suggestion, comparing the entrepreneurial approach by different ethnic groups in the same municipality, could yield results to help ascertain whether a context is generally perceived as favourable or hostile to ethnic entrepreneurship.

In both cases, precious information about the creation of new ethnic ventures could be obtained. Local governments could leverage on such information to achieve greater social and economic benefits from the phenomenon of ethnic entrepreneurship that with specific regard to Italy - has not yet shown its whole potential.

Competing interests

The authors declare that they have no competing interests.

\section{Authors' contribution}

DM authored the following paragraphs: "Background", "Conceptual framework and hypotheses", "Research methods", and "Results". MS authored the following paragraphs: "The characteristics of opportunity and necessity entrepreneurs" and "Discussion and conclusion". Both the authors read and approved the final manuscript.

Received: 4 January 2014 Accepted: 23 April 2014

Published: 30 Jul 2014

References

ABI - Italian Bankers Association. (2008). La relazione tra banche e migranti in Italia. Roma: Bancaria Editrice.

Aldrich, HE, \& Reiss, AJ. (1976). Continuities in the study of ecological succession: changes in the race composition of neighbourhoods and their businesses. American Journal of Sociology, 81(4), 846-866.

Aldrich, HE, \& Waldinger, R. (1990). Ethnicity and entrepreneurship. Annual Review of Sociology, 16(1), 111-135.

Aldrich, HE, Zimmer, C, \& McEvoy, D. (1989). Continuities in the study of ecological succession: Asian business in three English cities. Social Forces, 67(4), 920-944.

Aldrich, HE, Waldinger, R, \& Ward, R. (1990). Ethnic entrepreneurs. London: Sage Publications.

Allen, WD. (2000). Social network and self-employment. Journal of Socio-Economics, 29(5), 487-501.

Altinay, L, \& Altinay, E. (2006). Factors influencing business growth: the rise of Turkish Entrepreneurship in the UK. International Journal of Entrepreneurial Behaviour and Research, 14(1), 24-46.

Ambrosini, M. (2000). Utili invasori. Franco Angeli, Milano: L'Inserimento degli immigrati nel mercato del lavoro italiano.

Ambrosini, M, \& Abbatecola, E. (2002). Reti di relazione e percorsi di inserimento lavorativo degli stranieri: l'imprenditorialità egiziana a Milano. In A Colombo \& G Sciortino (Eds.), Stranieri in Italia (Assimilatith ed.). Bologna: Esclusi. II Mulino.

Anna, AL, Chandler, GN, Jansen, E, \& Mero, NP. (1999). Women business owners in traditional and non-traditional industries. Journal of Business Venturing, 15(3), 279-303.

Atallah, N, \& Rebelo, S. (2006). Recognition of credit history for new immigrants. Halifax, Nova Scotia.: Atlantic Metropolis Centre, Economics domain, metropolitan immigrant settlement association (MISA).

Bailey, T, \& Waldinger, R. (1991). The Changing Ethnic/Racial Division of Labour. In JH Mollenkopf \& M Castells (Eds.), Dual City: Restructuring New York. New York: Russell Sage.

Bank of England. (1999). The financing of ethnic minority firms. London: The Bank of England. 
Barrett, G, Jones, T, \& McEvoy, D. (1996). Ethnic minority business, theoretical discourse in Britain and North America. Urban Studies, 33(4-5), 783-809.

Basu, A. (1998). An exploration of entrepreneurial activity among Asian small businesses in Britain. Small Business Economics, 10(4), 313-326.

Basu, A, \& Altinay, E. (2002). The interaction between culture and entrepreneurship in London's immigrant businesses. International Small Business Journal, 20(4), 371-393.

Basu, A, \& Goswani, A. (1999). South Asian entrepreneurship in Great Britain: factors influencing growth. International Journal of Entrepreneurial Behaviour \& Research, 5(5), 251-275.

Bates, T. (1989). The changing nature of minority business: a comparative analysis of Asian, non-minority and black-owned Business. The Review of Black Political Economy, 18(2), 25-42.

Bates, T. (1994). An analysis of Korean-immigrant-owned small business start-ups with comparison to African-American small businesses and nonminority-owned firms. Small Business Economics, 10(4), 313-326.

Bates, T. (1997). Finance small business creation: the case of Chinese and Korean immigrant entrepreneurs. Journal of Business Venturing, 12(2), 109-124.

Baumol, WJ. (1990). Entrepreneurship, productive, unproductive and destructive. The Journal of Political Economy, 98(5), 893-921.

Block, JH, \& Wagner, M. (2007). Opportunity recognition and exploitation by necessity and opportunity entrepreneurs: empirical evidence from earnings equations. In Proceedings of the Sixty-Sixth Annual Meeting of Academy of Management. Philadelphia (PA): Academy of Management.

Bonacich, E, \& Modell, J. (1980). The economic basis of ethnic solidarity: small business in the Japanese American community. Berkley and Los Angeles: University of California Press.

Boyd, RL. (1989). Minority status and childlessness. Sociological Inquiry, 59(3), 331-343.

Boyd, RL. (1990). Black and Asian self-employment in large metropolitan areas: a comparative analysis. Social Problems, $37(2), 258-274$

Bressan, M, Fanfani, D, \& Radini, M. (2008). Prato: dalla città fabbrica alla società multiculturale. In L Fregolent (Ed.), Periferia e Periferie. Roma: Aracne.

Breveglieri, L, Cologna, D, Farina, P, \& Lanzani, A. (1997). Cina a Milano. Famiglie ambienti e lavori della popolazione cinese a Milano. Milano: Abitare Segesta Cataloghi.

Breveglieri, L, Cologna, D, Farina, P, \& Lanzani, A. (2000). Africa a Milano. Famiglia, ambienti e lavori delle popolazioni africane a Milano. Milano: Abitare Segesta Cataloghi.

Brush, C, Carter, N, Gatewood, E, Greene, P, \& Hart, M. (2001). The Diana Project. Women business owners and equity capital: the myths dispelled. Report for Kauffman Centre for Entrepreneurial Leadership. available at www.kauffman.org.

Butler, J. (1991). Entrepreneurship and self-help among Black Americans: a reconsideration of race and economics. Albany, NY: State University of New York Press.

Buttner, EH, \& Moore, DP. (1997). Women's organizational exodus to entrepreneurship: self-reported motivations and correlates with success. Journal of Small Business Management, 35(1), 34-46.

Ceccagno, A. (2003). Migranti a Prato. Franco Angeli, Milano: II distretto tessile multietnico.

CeSPI. (2004). Banche italiane e clientela immigrata. Rimesse, risparmio e credito: le iniziative in atto e le prospettive di crescita. Roma: Bancaria Editrice.

Chaganti, R, \& Greene, P. (2002). Who are ethnic entrepreneurs? A study of entrepreneurs' ethnic involvement and business characteristics. Journal of Small Business Management, 40(2), 126-143.

Chiesi, AM. (2011). Il profilo nazionale degli immigrati imprenditori. Final report of PRIN 2007. available at www. ilsole24ore.com.

Chiesi, AM, \& Zucchetti, E. (2003). Immigrati imprenditori. Egea, Milano: II contributo degli extracomunitari allo sviluppo della piccola impresa in Lombardia.

Christopher, J. (1998). Minority business formation and survival: evidence on business performance and viability. Review of Black Political Economy, 26(1), 37-72.

Chrysostome, E. (2010). The success factors of necessity immigrant entrepreneurs: in search of a model. Thunderbird International Business Review, 52(2), 137-152.

Chrysostome, E, \& Arcand, S. (2009). Survival of necessity immigrant entrepreneurs: an exploratory study. Journal of Comparative International Management, 12(2), 3-29.

Clark, K, \& Drinkwater, S. (2000). Pushed out or pulled in? Self-employment among ethnic minorities in England and Wales. Labour Economics, 7(5), 603-628.

Clark, K, \& Drinkwater, S. (2002). Enclaves, neighbourhood effects and employment outcomes: ethnic minorities in England and Wales. Journal of Population Economics, 15(1), 5-29.

Clark, K, \& Drinkwater, S. (2010). Recent trends in minority ethnic entrepreneurship in Britain. International Small Business Journal, 28(2), 136-146.

Cobas, JA, \& DeOllos, I. (1989). Family ties, co-ethnic bond, and ethnic entrepreneurship. Sociological Perspectives, 32(3), 403-411.

Daniels, PW. (1993). Service Industries in the World Economy. Oxford: Blackwell.

Daniels, PW, \& Lever, WF. (1996). The Global Economy in Transition. Harlow, Essex: Addison Wesley Longman.

De Freitas, G. (1991). Inequality at Work: Hispanics in the U.S. Labor Force. New York: Oxford University Press.

de Haas, H. (2010). Migration and development: a theoretical perspective. International Migration Review, 44(1), 227-264.

Deakins, D. (1999). Entrepreneurship and Small Firms (2nd ed.). London: McGraw Hill.

Deakins, D, Majunder, M, \& Paddison, A. (1997). Developing success strategies for ethnic minorities in business: evidence from Scotland. New Community, 23(3), 325-342.

Deakins, D, Ishaq, M, Smallbone, D, Whittam, G, \& Wyper, J. (2007). Ethnic minority business in Scotland and the role of social capital. International Small Business Journal, 25(3), 307-326.

Drori, I, Honig, B, \& Wright, M. (2009). Transnational entrepreneurship: an emergent field of study. Entrepreneurship: Theory and Practice, 33(5), 1001-1022. 
Elmlund, P. (2005). Immigrazione: centri storici, commercio, industrialismo e urbanistica moderna in una prospettiva insolita. Metronomie, 30, 261-271.

Evans, MDR. (1989). Immigrant entrepreneurship: effects of ethnic market size and isolated labour pool. American Sociological Journal, 54(6), 950-962.

Fadahunsi, A. (2000). Researching informal entrepreneurship in Sub-Saharan Africa: a note on field methodology. Journal of Developmental Entrepreneurship, 5(3), 249-260.

Fairlie, RW, \& Meyer, BD. (1996). Ethnic and racial self-employment: differences and possible explanations. The Journal of Human Resources, 31(4), 757-793.

Feagin, JR, \& Imani, N. (1994). Racial barriers to African entrepreneurship: an exploratory study. Social Problems, 41(4), 562-584.

Fischer, EM, Reuber, AR, \& Dyke, LS. (1993). A theoretical overview and extension of research on sex, gender and entrepreneurship. Journal of Business Venturing, 8(2), 151-168.

Flota, C, \& Mora, M. (2001). The earnings of self-employed Mexican-Americans along the US-Mexico border. Annals of Regional Science, 35(3), 483-499.

Fondazione Ethnoland. (2009). Immigrati/Imprenditori in Italia. Edizioni Idos, Roma: Dinamiche del fenomeno: analisi, storie, prospettive.

Fraser, S. (2009). Is there ethnic discrimination in the UK market for small business credit? International Small Business Journal, 27(5), 583-607.

Fregetto, E. (2004). Immigrant and ethnic entrepreneurship: a US perspective. In HP Welsch (Ed.), Entrepreneurship: The Way Ahead. New York: Routledge.

Ganzaroli, A, Pilotti, L, De Noni, I, \& Orsi, L. (2008). Report for "Imprese e Imprenditorialità Multiculturali tra Varietà e Innovazione nei Sistemi Produttivi Locali e Metropolitani". Milan: Università degli Studi di Milano.

Giacomin, O, Guyot, JL, Janssen, F, \& Lohest, O. (2007). Novice Creators: Personal Identity and Push Pull Dynamics. In Working Paper for 52nd International Council for Small Business World Conference Proceedings. Turku (Finland): ICSB.

Giacomin, O, Janssen, F, Guyot, J, \& Lohest, O. (2011). Opportunity and/or necessity entrepreneurship? The impact of the socio-economic characteristics of entrepreneurs (MPRA Paper No. 29506). Germany: University Library of Munich.

Gilad, B, \& Levine, P. (1986). A behavioural model of entrepreneurial supply. Journal of Small Business Management 24(4), 45-53.

Gohmann, S, Hobbs, BK, \& McCrikard, M. (2008). Economic freedom and service industry growth in the United States. Entrepreneurship: Theory and Practice, 32(5), 855-874.

Gold, SJ. (2001). Gender, class, and networks: social structure and migration patterns among transnational Israelis. Global Networks, 1(1), 19-40.

Guarnizo, LE, Portes, A, \& Haller, W. (2003). Assimilation and trans-nationalism: determinants of transnational political action among contemporary migrants. American Journal of Sociology, 108(6), 1121-1148.

Harding, R, Brooksbank, D, Hart, M, Jones-Evans, D, Levie, J, O'Reilly, J, \& Walker, J. (2006). Global Entrepreneurship Monitor: Country Report United Kingdom 2005. London: London Business School.

Hussain, J, \& Martin, L. (2005). New Asian entrepreneurship: exploring finance and innovation. Blackpool, UK. Paper Presented to the 27th ISBA National Small Firms Policy and Research Conference on SMEs in the Knowledge Economy.

Hussain, J, \& Matlay, H. (2007). Financing preferences of ethnic minority owner/manager in the UK. Journal of Small Business and Enterprise Development, 14(3), 487-500.

Irwin, D, \& Scott, JM. (2006). Barriers faced by SMEs in raising finance from banks. Cardiff: Paper Presented at the ISBE Conference.

Johannisson, B. (1993). Designing supportive contexts for emerging enterprises. In C Karlsson, B Johannisson, \& D Storey (Eds.), Small Business Dynamics. Routledge, London: International, National and Regional Perspective.

Johnson, PJ. (2000). Ethnic differences in self-employment among Southeast Asian refugees in Canada. Journal of Small Business Management, 38(4), 78-86.

Kalleberg, AL, \& Leitch, KT. (1991). Gender and organizational performance: determinants of small business survival and success. Academy of Management, 34(1), 136-161.

Katila, S, \& Wahlbeck, Ö. (2011). The role of (transnational) social capital in the start-up processes of immigrant businesses: the case of Chinese and Turkish restaurant businesses in Finland. International Small Business Journal, 30(3), 294-309.

Kerr, G, \& Schlosser, F. (2007). Start-up and success in ethnic new ventures. Frontiers of Entrepreneurship Research, 27(5), 166-181.

Kim, KC, \& Hurh, WM. (1985). Ethnic resources utilization of Korean immigrant entrepreneurs in the Chicago minority area. International Migration Review, 19(1), 82-111.

Kloosterman, RC. (2003). Creating opportunities. Policies aimed at increasing openings for immigrant entrepreneurs in the Netherlands Entrepreneurship and Regional Development, 15(2), 167-181.

Kloosterman, RC, \& Rath, J. (2001). Immigrant entrepreneurs in advanced economies: mixed embeddedness further explored. Journal of Ethnic and Migration Studies, 27(2), 1-14.

Kloosterman, RC, Van der Leun, JP, \& Rath, J. (1998). Across the border; economic opportunities, social capital and informal business activities of immigrants. Journal of Ethnic Migration Studies, 24(2), 249-268.

Kloosterman, RC, Van der Leun, JP, \& Rath, J. (1999). Mixed embeddedness, migrant entrepreneurship and informal economic activities. International Journal of Urban and Regional Development, 23(2), 253-367.

Kon, Y, \& Storey, DJ. (2003). A theory of discouraged borrowers. Small Business Economics, 21(1), 37-49.

Le, AT. (2000). The determinants of immigrants self-employment in Australia. International Migration Review, 34(1), 183-214.

Lee, J. (1999). Retail niche domination among African American, Jewish, and Korean entrepreneurs. American Behavioral Scientist, 42(9), 1398-1416

Lee, Y, Cameron, T, Schaffer, P, \& Schmidt, CG. (1997). Ethnic minority small business: a comparative analysis of restaurants in Denver. Urban Geography, 18(7), 591-621.

Light, I. (1972). Ethnic entrepreneurs in America. Berkeley, CA: University of California Press.

Light, I, \& Bonacich, E. (1988). Immigrant entrepreneurs: Koreans in Los Angeles 1965-1982. Berkeley and Los Angeles: University of California Press. 
Light, I, \& Gold, S. (2000). Ethnic economies. San Diego, CA: San Diego Academic Press.

Light, I, Sabagh, G, Bozorgmehr, M, \& Der-Martirosian, C. (1994). Beyond the ethnic enclave economy. Social Problems, $41(1), 65-80$.

Lofstrom, M. (2002). Labour market assimilation and the self-employment decision of immigrant entrepreneurs. Journal of Population Economics, 15(1), 83-114.

Ma Mung, E. (1992). L'expansion du commerce ethnique: Asiatiques et Maghrébins dans la Région Parisienne. Revue Européenne des Migrations Internationales, 8(1), 39-59.

Maggioni, V, Sorrentino, M, \& Williams, M. (1999). Mixed Consequences of Government Aid for New Venture Creation: Evidence from Italy. Journal of Management and Governance, 3(3), 287-305.

Maritz, A. (2004). New Zealand necessity entrepreneurs. International Journal of Entrepreneurship and Small Business, 1(3-4), 255-264.

Martes, A. (2000). Brazilians in the United States: a study on immigrants in Massachusetts. Sao Paolo: Pas ex terra.

Martiniello, M. (2000). Le società multietniche: diritti e doveri uguali per tutti? Bologna: II Mulino Contemporanea.

Masurel, E, Nijkamp, P, Tastan, M, \& Vindigni, G. (2002). Motivations and performance conditions for ethnic entrepreneurship. Growth and Change, 33(2), 238-260.

Mata, R, \& Pendakur, R. (1999). Immigration, labor force integration, and the pursuit of self-employment. International Migration Review, 33(2), 378-402.

Matricano, D. (2011a). La creazione di imprese etniche: aspetti teorici ed evidenze empiriche (Napoli: Enzo Albano Editore).

Matricano, D. (2011b). Ukrainian Entrepreneurship in Caserta: An Empirical Investigation (pp. 1205-1214). Elounda, Crete, Greece: Paper Presented at the 4th Conference of the Euromed Academy of Business (EMAB).

Matricano, D, \& Sorrentino, M. (2012). The Break-out process: Evidences from the South of Italy (pp. 1040-1050). Glion-Montreux, Switzerland: Paper Presented at the 5th Annual Euromed Conference.

Maxim, PS. (1992). Immigrants, visible minorities, and self-employment. Demography, 29(2), 181-198.

McClelland, E, Swail, J, Bell, J, \& Ibbotson, P. (2005). Following the pathway of female entrepreneurs: a six-country investigation. International Journal of Entrepreneurial Behaviour \& Research, 11(2), 84-107.

Min, P. (1992). The structures and social functions of Korean immigrant churches in the United States. International Migration Review, 26(4), 1370-1394.

Min, P, \& Bozorgmehr, M. (2000). Immigrant entrepreneurship and business patterns: a comparison of Korean and Iranians in Los Angeles. International Migration Review, 34(3), 707-738.

Min, P, \& Bozorgmehr, M. (2003). USA: the entrepreneurial cutting edge. In R Kloosterman \& J Rath (Eds.), Immigrant entrepreneurs: venturing abroad in the age of globalization. New York: Berg.

Minniti, M. (2008). The role of government policy on entrepreneurial activity: productive, unproductive and destructive? Entrepreneurship: Theory and Practice, 32(5), 770-790.

Minniti, M, Bygrave, W, \& Autio, E. (2006). Global Entrepreneurship Monitor: Executive Report 2005. London: London Business School.

Moore, RL. (1983). Employer discrimination: evidence from self-employed workers. Review of Economics and Statistics, 65(3), 496-501.

Moore, LM, \& Rickel, AU. (1980). Characteristics of women in traditional and non-traditional roles. Personnel Psychology, $33,317-333$.

Nee, V, \& Nee, B. (1973). Longtime Californ' (Pantheon Books). New York: A documentary study of American Chinatown.

Ong, A. (1999). Flexible citizenship: the cultural logics of transnationality. Durham: Duke University Press.

Ong, A, \& Nonini, D. (1997). Ungrounded empires: the cultural politics of modern Chinese transnationalism. New York: Routledge.

Palidda, S. (2000). Socialità e inserimento degli immigrati a Milano. Milano, Franco Angeli: Una ricerca per il Comune di Milano.

Parker, SC. (2004). The economics of self-employment and entrepreneurship. Cambridge: Cambridge University Press.

Pécoud, A. (2004). Entrepreneurship and identity: cosmopolitan and cultural competencies among German-Turkish businesspeople in Berlin. Journal of Ethnic and Migration Studies, 30(1), 3-20.

Peterson, MF, \& Roquebert, J. (1993). Success patterns of Cuban-American enterprises: implications for entrepreneurial communities. Human Relations, 46(8), 921-937.

Phizacklea, A, \& Ram, M. (1996). Being your own boss: ethnic minority entrepreneurs in comparative perspective. Work, Employment \& Society, 10(2), 319-339.

Pio, E. (2007). Ethnic entrepreneurship among Indian women in New Zealand: a bittersweet process. Gender, Work and Organization, 14(5), 409-432.

Portes, A. (1995). The economic sociology of immigration (Essays on networks, ethnicity and entrepreneurship). New York: Russel Sage Foundation.

Portes, A, \& Bach, R. (1985). Latin journey: a longitudinal study of Cuban and Mexican immigrants in the US. Berkeley: University of California Press.

Portes, A, \& Zhou, M. (1992). Gaining the upper hand: economic mobility among immigrant and domestic minorities. Ethnic and Racial Studies, 15(4), 491-522.

Rafiq, M. (1992). Ethnicity and enterprise: a comparison of Muslim and non-Muslin owned Asian business in Britain. New Community, 19(1), 43-60.

Ram, M. (1994). Unraveling social networks in ethnic minority firms. International Small Business Journal, 12(3), 42-59.

Ram, M, \& Deakins, D. (1996). African-Caribbeans in business. New Community, 22(1), 67-84.

Ram, M, \& Hillin, G. (1994). Achieving break-out: developing mainstream ethnic minority businesses. Small Business and Enterprises Development, 1(2), 15-21.

Razin, E, \& Langlois, A. (1996). Metropolitan characteristics and entrepreneurship among immigrants and ethnic groups in Canada. International Migration Review, 30(3), 703-727.

Reynolds, PD, Camp, SM, Bygrave, WD, Autio, E, \& Hay, M. (2001). Global Entrepreneurship Monitor: Executive Report (pp. 1-59). London: Babson College, London Business School and Kauffman Foundation. 
Reynolds, PD, Bygrave, WD, Autio, E, Cox, LW, \& Hay, M. (2002). Global Entrepreneurship Monitor: Executive Report 2002 (pp. 1-47). London: Babson College, London Business School and Kauffman Foundation.

Robb, AM, \& Fairlie, RW. (2007). Determinants of Business Success and Empirical Examination of Asian-owned Business in the United States (pp. 1-56). Bonn (Germany): Institute for the Study of Labor - IZA Discussion Paper No. 2566.

Robichaud, Y, LeBrasseur, R, \& Nagarajan, KV. (2010). Necessity and opportunity-driven entrepreneurs in Canada: an investigation into their characteristics and an appraisal of the role of gender. Journal of Applied Business and Economics, 11(1), 59-79.

Sanders, JM, \& Nee, V. (1987). Limits of ethnic solidarity in the enclave economy. American Sociological Review, 52(6), $745-773$.

Santi, RM. (1995). Un'indagine sul lavoro autonomo degli immigrati a Torino. Torino: Quaderni di Ricerca dell'Associazione IRES Lucia Morosini.

Sassen, S. (1991). The Global City. New York, London, Tokyo: Princeton University Press, Princeton, NJ.

Sequeira, JM, \& Rasheed, AA. (2006). Start-up and growth of immigrant small businesses: the impact of social and human capital. Journal of Development Entrepreneurship, 11(4), 357-375.

Shapero, A, \& Sokol, L. (1982). The social dimension of entrepreneurship. In C Kent, D Sexton, \& K Vesper (Eds.), Encyclopedia of entrepreneurship. Englewood Cliff, NJ: Prentice Hall.

Shinnar, RS, \& Young, CA. (2008). Hispanic immigrant entrepreneurs in the Las Vegas metropolitan area: motivations for entry into and outcomes of self-employment. Journal of Small Business Management, 46(2), 242-262.

Smallbone, D, \& Welter, F. (2004). Entrepreneurship in transition economies: necessity or opportunity drive? Report available at www.babson.edu.

Sorrentino, M. (2012). Entrepreneurial issues in competitive strategy research. In GB Dagnino (Ed.), Handbook of Research on Competitive Strategy. Cheltenham, UK: Edwar Elgar Publishing.

Sternberg, R, Brixy, U, \& Schlapfner, JF. (2006). Global Entrepreneurship Monitor: Country Report Germany 2005. Hannover: Institute of Economic and Cultural Geography, Leibnitz University of Hannover.

Stevenson, L. (1986). Against all odds: the entrepreneurship of women. Journal of Small Business Management, 24(4), 30-36.

Storey, DJ. (1994). Understanding the Small Business Sector. London: Routledge.

Uhlaner, LM, \& Thurik, AR. (2007). Post-materialism: a cultural factor influencing total entrepreneurial activity across nations. Journal of Evolutionary Economics, 17(2), 161-185.

Van Delf, H, Gorter, C, \& Nijkamp, P. (2000). In search of ethnic entrepreneurship opportunities in the city. Environment \& Planning C, 18(4), 429-451.

Verheul, I, Thurik, R, Hessels, J, \& Van der Zwan, P. (2010). Factors Influencing the Entrepreneurial Engagement of Opportunity and Necessity Entrepreneurs (EIM Research Reports, pp. 1-24).

Villar, M. (1994). Hindrances to development of an ethnic economy among Mexican migrants. Human Organization, 53(3), 263-268.

Vinogradov, E, \& Isaken, E. (2008). Survival of new firms owned by natives and immigrants in norway. Journal of Development Entrepreneurship, 13(1), 21-38.

Volery, T. (2007). Ethnic entrepreneurship: a theoretical framework. In L Dana (Ed.), Handbook of research on ethnic minority entrepreneurship. Cheltenham: Edward Elgar Publishing.

Wagner, J. (2005). Nascent necessity and opportunity entrepreneurs in Germany: evidence from the Regional Entrepreneurship Monitor (pp. 1-24). Bonn (Germany): Institute for the Study of Labor - IZA Discussion Paper No. 1608.

Waldinger, R. (1985). Immigration and industrial change in the New York City apparel industry. In G Borjas \& M Tienda (Eds.), Hispanics in the US Economy. New York: Academic.

Waldinger, R. (1986). Through the eye of the needle: imigrants and enterprise in New York's garment trades. New York: New York University Press.

Waldinger, R, Aldrich, H, \& Ward, R. (1990). Ethnic entrepreneurs: immigrant business in industrial societies. Newbury Park, CA: Sage.

Walton-Roberts, M, \& Hiebert, D. (1997). Immigration, entrepreneurship, and the family: Indo Canadian enterprise in the construction industry of greater Vancouver. Canadian Journal of Regional Science, 20(1-2), 119-147.

Washington, BT. (1971). The Negro in Business. New York: AMS Press.

Wilson, KL, \& Portes, A. (1980). Immigrants enclave: an analysis of the labor market experiences of Cubans in Miami. American Journal of Sociology, 86(2), 295-319.

XX Rapporto Caritas-Migrantes, \& Statistico, D. (2010). Dossier 1991-2010: Per una Cultura dell'Altro. Roma: Edizioni Idos.

Yoon, I. (1991). The changing significance of ethnic and class resources in immigrant business. International Migration Review, 25(2), 303-331.

Yoon, I. (1995). The growth of Korean immigrant entrepreneurship in Chicago. Ethnic and Racial Studies, 18(2), 315-335.

Zhou, M. (1992). China Town: the socio-economic potential of an urban enclave. Philadelphia: Temple University.

Zhou, M. (1995). Asian-American entrepreneurship: the causes and consequences. National Journal of Sociology, 2(9), 1-35.

Zhou, M. (2004). Revising ethnic entrepreneurship: convergences, controversies, and conceptual advancements. International Migration Review, 38(3), 1040-1074.

10.1186/2192-5372-3-10

Cite this article as: Matricano and Sorrentino: Ukrainian entrepreneurship in Italy: factors influencing the creation

of ethnic ventures. Journal of Innovation and Entrepreneurship 2014, 3:10 